DOI: https://doi.org/10.47405/mjssh.v7i1.1236

\begin{tabular}{|c|c|}
\hline 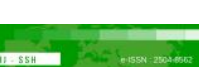 & Malaysian Journal of Social Sciences and Humanities (MJSSH) \\
\hline Malaysian Journal of & Volume 7, Issue 1, January 2022 \\
\hline $\begin{array}{l}\text { Humantites } \\
\text { (MJ-sSH) }\end{array}$ & e-ISSN : 2504-8562 \\
\hline & $\begin{array}{l}\text { Journal home page: } \\
\text { www.msocialsciences.com }\end{array}$ \\
\hline
\end{tabular}

\title{
Persekitaran Fizikal Pembelajaran dan Indeks Keselesaan Guru Program Pendidikan Khas Integrasi Daerah Kota Kinabalu
}

\author{
Shera Binti Jouflin', Mohd Hanafi Bin Mohd Yasin' ${ }^{1}$ \\ 1Fakulti Pendidikan, Universiti Kebangsaan Malaysia (UKM), Malaysia \\ Correspondence: Shera Binti Jouflin (sherajouflin87@gmail.com)
}

\begin{abstract}
Abstrak
Tahap persekitaran fizikal bilik darjah memberi kesan kepada pelaksanaan proses pendidikan. Kajian ini dijalankan bagi mengenal pasti indeks keselesaan bagi persekitaran fizikal pembelajaran Program Pendidikan Khas Integrasi (PPKI), indeks keselesaan guru dalam pengajaran dan pembelajaran serta cadangan-cadangan penambahbaikan bilik darjah PPKI di daerah Kota Kinabalu. 80 orang sampel guru PPKI telah dipilih secara pensampelan bertujuan. Soal selidik kajian diadaptasi daripada Inventori Kesejahteraan dan Keselesaan Pembelajaran (IKKP) dan Inventori Persekitaran Fizikal Bilik Darjah (IPFBD). Penyebaran soal selidik dilakukan secara atas talian melalui "Google Form". Statistical Package for the Social Science (SPSS) versi 26 digunakan untuk menganalisis dapatan kajian secara analisis deskriptif. Dapatan kajian menunjukkan indeks keselesaan persekitaran fizikal bilik darjah PPKI daerah Kota Kinabalu adalah tinggi $(\mathrm{M}=3.94, \mathrm{SP}=0.627)$ dan Indeks keselesaan guru terhadap pengajaran dan pembelajaran turut mencatat indeks yang tinggi $(\mathrm{M}=3.90, \mathrm{SP}=0.688)$. Analisis pada soal selidik terbuka mendapati keselesaan persekitaran bilik darjah dapat ditingkatkan melalui penambahbaikan pada aspek perabot, ruang pembelajaran, bilangan murid, pencahayaan, kualiti udara dan warna dinding bilik darjah. Kajian ini adalah berasaskan Teori Kebajikan Sosiologikal Allardt dan Universal Design Learning (UDL). Implikasi daripada kajian ini, pemegang taruh boleh membuat penilaian dan penyelenggaraan pada fizikal bilik darjah PPKI bagi mewujudkan persekitaran pembelajaran yang kondusif.
\end{abstract}

Kata kunci: persekitaran fizikal, program pendidikan khas integrasi, indeks keselesaan, kesejahteraan, pengurusan bilik darjah

\section{Learning Physical Environment and Comfort Index of Special Education Integrated Programme Teacher of Kota Kinabalu District}

\begin{abstract}
Physical classrooms affect the implementation of the educational process. This study was conducted to identify the comfort index for the physical learning environment of the Special Education Integration Program (SEIP), the comfort index of teachers in teaching and learning as well as suggestions for improving the SEIP classroom in the district of Kota Kinabalu. 80 SEIP teachers were selected by purposive sampling. The study questionnaire was adapted from the Learning Wellness and Comfort Inventory (IKKP) and Physical Classroom Environment Inventory (IPFBD). Questionnaire distribution is done online through "Google Form". Statistical Package for the Social Science (SPSS) version 26 was used to analyze the findings of the study by descriptive analysis. The findings showed that the comfort index of the physical environment of the SEIP classroom in Kota Kinabalu district was high
\end{abstract}


$(\mathrm{M}=3.94, \mathrm{SP}=0.627)$ and the comfort index of teachers towards teaching and learning also recorded a high index $(\mathrm{M}=3.90, \mathrm{SP}=0.688)$. Analysis of the open-ended questionnaire found that the comfort of the classroom environment can be improved through improvements in aspects of furniture, learning space, ideal number of students in the classroom, lighting, air quality and colour of classroom walls. This study is based on Allardt's Theory of Sociological Welfare and Universal Design Learning (UDL). Implications from this study, stakeholders can make assessment and maintenance on the physical of the SEIP classroom to create a conducive learning environment.

Keywords: physical environment of the classroom, Special Education Integration Program, comfort index, well-being, classroom management

\section{Pengenalan}

Berikutan daripada pandemik Covid-19, sektor pendidikan negara menghadapi cabaran menyediakan sistem pendidikan yang holistik, komprehensif dan bermutu. Lantaran itu, Kementerian Pendidikan Malaysia (KPM) amat menekankan keselesaan ruang pembelajaran. Fizikal pembelajaran terdiri daripada ruangan pembelajaran, pencahayaan, akustik, keselesaan termal (Gislason, 2011; Scrivener, 2012), meja, kerusi, papan putih dan rak (Doyle, 1980). Persekitaran fizikal bilik darjah haruslah dapat menyokong pembelajaran dan pengajaran (Rands \& Gansemer-Topf, 2017). Penyediaan bilik darjah yang kurang kondusif berupaya mempengaruhi tahap motivasi guru dalam pekerjaan (Mohd Arafat et al., 2021) dan perkembangan akademik murid berkeperluan Khas (MBK).

Guru bertanggungjawab mengurus bilik darjah dengan sistematik. Pengurusan faktor fizikal pembelajaran adalah penting bagi memastikan persekitaran pembelajaran berada dalam keadaan kondusif (Akhiar \& Shamsina, 2015; Juairiah et al., 2020). Pengurusan yang sistematik akan membawa kepada disiplin bilik darjah yang baik (Aney \& Norasmah, 2019; Sieberer-Nagler, 2015). Kelemahan pengurusan bilik darjah akan mempengaruhi kesihatan emosi (Korpershoek et al. 2016; Norfisah, 2016) dan tingkah laku murid berkeperluan khas (Kanakriz et al., 2016; Tegtmejer, 2019). Berikutan itu, kajian pengurusan bilik darjah perlu dilaksanakan bagi mendapatkan pemahaman yang lebih baik mengenai kemahiran pengurusan bilik darjah yang berkesan.

World Health Organization (WHO) menekankan kesihatan pekerjaan perlu mengambil kira tahap psikologi, sosiologi dan mental pekerja. Selari dengan Teori Kebajikan Sosiologikal Allardt, persekitaran iklim sekolah yang kondusif berupaya mempengaruhi indeks keselesaan pengajaran. Aspek keselesaan khususnya kecerdasan emosi yang baik adalah penting bagi guru (Ajilin et al., 2020). Persekitaran pekerjaan yang kurang kondusif mempengaruhi fizikal dan emosi guru (Amalina \& Azita, 2016; Ng et al., 2019; Suhaimi \& Muhamad Suhaimi, 2020). Sehubungan itu, pihak pengurusan perlu memastikan ergonomik persekitaran pekerjaan boleh meningkatkan keselesaan guru.

Kajian-kajian lalu mendapati terdapat pelbagai faktor yang menyumbang kepada tekanan guru di sekolah. Dana (Farah et al., 2021; Mohd Razimi et al., 2020) dan sokongan pentadbir (Amalina \& Azita, 2016; Mohd Arafat et al., 2021) adalah antara faktor yang dikenal pasti mempengaruhi iklim sesebuah sekolah. Kajian secara sistematik mengenai indeks keselesaan guru berupaya menyumbang kepada penambahbaikan fizikal pembelajaran.

Kajian ini boleh digunakan oleh guru serta pengurusan pendidikan dalam perancangan persekitaran pendidikan berpandukan Universal Design for Learning (UDL). Kajian lalu menunjukkan bilik darjah PPKI berada pada tahap yang rendah (Anselm et al., 2018; Norsafiah et al., 2021). Dapatan kajian lalu menekankan bilik darjah PPKI memerlukan penyelenggaraan (Mohd Hanafi et al., 2013; Mohd Razimi et al., 2020; Norwahidah et al., 2019). Sehubungan itu kajian lanjutan perlu dilakukan bagi menguji kesesuaian bilik darjah dengan keperluan pendidikan MBK khususnya dalam keadaan norma baharu ini. 
DOI: https://doi.org/10.47405/mjssh.v7i1.1236

Kajian berfokuskan bilik darjah PPKI berupaya meneroka permasalahan yang berkaitan fizikal pembelajaran. Sehubungan itu, kajian ini adalah bertujuan untuk:

i. Mengenal pasti indeks keselesaan persekitaran fizikal bilik darjah PPKI Murid berkeperluan Khas (MBK) pembelajaran di daerah Kota Kinabalu.

ii. Mengenal pasti indeks keselesaan pengajaran dan pembelajaran guru PPKI MBK pembelajaran di daerah Kota Kinabalu.

iii. Mengenal pasti cadangan-cadangan penambahbaikan bagi persekitaran fizikal bilik darjah PPKI MBK pembelajaran di daerah Kota Kinabalu.

\section{Sorotan Literatur}

Ergonomik fizikal bilik darjah adalah penting bagi proses pendidikan. Perabot khususnya meja dan kerusi yang tidak seragam dan ergonomik akan mendedahkan murid dengan risiko gangguan muskuloskeletal (Wahyuni et al., 2014). Kajian Norsafiah et al. (2021) dan Anselm et al. (2018) menunjukkan terdapat bangunan sekolah yang tidak menepati standard reka bentuk bilik darjah. Selain itu, kelas pendidikan khas mengalami variasi cahaya yang tidak seimbang (Wan Nur Amirah et al, 2018), kelemahan akustik (Hamdi et al, 2012; Zarina, 2019) dan bilik darjah yang panas. Ini memberi kesan terhadap kehadiran murid (Mohd Zuri, 2020; Norsafiah et al., 2021). Oleh yang demikian, guru perlu memastikan fizikal bilik darjah berada pada tahap yang kondusif khususnya ketika pandemik Covid-19 ini.

\section{Model Kesejahteraan Sekolah}

Model Kesejahteraan Sekolah ini adalah dibina berdasarkan Teori Kebajikan Sosiologikal Allardt yang dipengaruhi oleh pembelajaran, pengajaran dan pendidikan. Ketiga-tiga domain ini adalah berkaitan dengan dimensi kepunyaan, kasih sayang, manusia dan kesihatan. Berdasarkan Rajah 1, kajian ini akan mengkaji faktor fizikal bilik darjah yang akan mempengaruhi pelaksanaan pengajaran oleh guru dan pembelajaran murid. Konu et al. (2002) menyatakan Model Kesejahteraan Sekolah ini boleh digunakan sebagai kerangka dalam merancang persekitaran fizikal sekolah yang kondusif. Berikut merupakan Rajah 1 iaitu Model Kesejahteraan Sekolah:

Rajah 1 : Model Kesejahteraan Sekolah

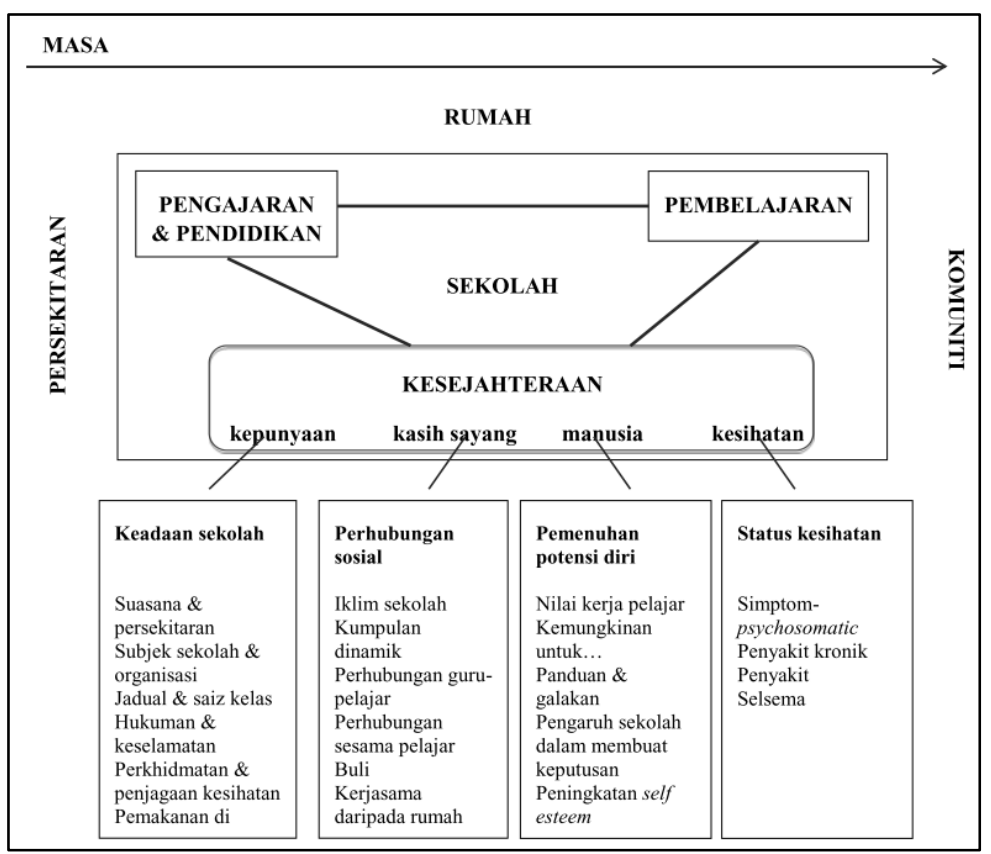

Sumber : Diadaptasi daripada Teori Kebajikan Sosiologikal Allardt (Konu et al., 2002) 
Kajian ini secara khususnya akan mengkaji suasana dan persekitaran bilik darjah yang merangkumi tahap pengudaraan, pencahayaan, warna, ruang dan perabot. Elemen-elemen ini dijangka berupaya mempengaruhi indeks keselesaan guru dan murid.

\section{Fizikal pembelajaran dan indeks keselesaan}

Bagi memenuhi aspirasi pendidikan berdasarkan Pelan Pembangunan Pendidikan Malaysia (20132025), pengurusan persekitaran pembelajaran adalah penting bagi proses pendidikan. Persekitaran fizikal bilik darjah berupaya mempengaruhi kesihatan fizikal, emosi (Amalina \& Azita, 2016; $\mathrm{Ng}$ et al., 2019; Suhaimi \& Muhamad Suhaimi, 2020) dan motivasi guru (Ahmad Syarifuddin et al, 2021; Junaidah et al., 2021; Mohd Arafat et al., 2021).

Kajian oleh Izzati et al. (2021) mendapati guru tidak berasa tertekan dan tidak mempunyai masalah untuk memberi sumbangan kewangan bagi meningkatkan keceriaan kelas. Namun demikian, beberapa kajian lalu menekankan isu guru perlu mencari dana sendiri, tidak mempunyai sokongan dalam penyediaan bahan pengajaran (Farah et al., 2021), kelelahan mengurus tingkah laku (Mohd Arafat et al., 2021) dan kekurangan tempat untuk melakukan aktiviti (Amalina \& Azita, 2016). Dapatan penyelidikan lalu ini menunjukkan dapatan yang tidak konsisten pada keselesaan guru. Malah, keselesaan guru daripada aspek fizikal bilik darjah PPKI juga kurang dibincangkan. Oleh itu, terdapat keperluan pada lanjutan kajian yang mengkaji indeks keselesaan khususnya bagi guru PPKI pada bilik darjah pendidikan khas.

Penilaian bilik darjah menyumbang kepada proses penambahbaikan infrastruktur sekolah. Nurwahidah (2019) dan Mohd Hanafi et al. (2013) menyatakan PPKI perlu mempunyai bangunan khas tersendiri. Indeks keselesaan fizikal pembelajaran secara amnya juga dapat ditingkatkan dengan cahaya buatan (Doulos, et al., 2019; Wan Nur Amirah et al., 2018), pencahayaan dan pengudaraan semua jadi (Farjana \& Muhammad Mozammel, 2019), blok pengudaraan (Norhaslin et al., 2019) dan reka bentuk tingkap yang sesuai (Ernisuhani et al., 2019; Ibhadode et al., 2017). Cadangan secara terbuka daripada kajian membolehkan analisis penambahbaikan diterokai berdasarkan iklim bilik darjah di Malaysia. KPM perlu lebih terbuka dalam menerima cadangan guru-guru bagi meningkatkan mutu pendidikan (Amalina \& Azita, 2016).

\section{Metod Kajian}

\section{Reka Bentuk Kajian}

Kajian ini adalah kajian kuantitatif dengan reka bentuk kajian tinjauan. Menurut Cohen et al. (2018), analisis data kuantitatif adalah bentuk penyelidikan yang kuat dan sering digunakan pada penyelidikan skala besar dan kecil kerana kelebihan pada kaedah kajian berbentuk penelitian, tindakan dan eksperimen. Melalui kaedah kajian ini, pengkaji berupaya mengembangkan konsep dan pemahaman dengan melihat kesesuaian dapatan dengan model dan teori (Taylor et al., 2016). Reka bentuk kajian akan mempengaruhi dapatan kajian ini.

\section{Lokasi Kajian}

Kajian ini dijalankan di daerah Kota Kinabalu, Sabah. Sekolah yang terlibat adalah terdiri daripada sekolah yang mempunyai PPKI. Sekolah-sekolah yang dipilih adalah antara sekolah luar bandar dan bandar yang mempunyai enrolmen MBK yang tinggi.

\section{Populasi dan Sampel Kajian}

Populasi kajian ini terdiri daripada guru Program Integrasi Pendidikan Khas (PPKI) daerah Kota Kinabalu, Sabah. Populasi guru PPKI daerah Kota Kinabalu ialah 122 orang. Seramai 80 sampel yang telah dipilih secara pensampelan bertujuan terlibat dalam kajian. Sampel kajian dipilih adalah daripada 
DOI: https://doi.org/10.47405/mjssh.v7i1.1236

11 buah sekolah. Pemilihan "Google Form” adalah antara alternatif yang digunakan dalam kajian ini. Pengkaji boleh mendapatkan jawapan dengan lebih mudah dan cepat berbanding menggunakan soal selidik yang dicetak (Fauziah et al., 2020). Responden kajian menjawab soalan melalui pautan "Google Form" yang diberikan oleh pengkaji.

\section{Instrumen Kajian}

Instrumen dirujuk sebagai set soal selidik untuk menarik perhatian pembaca bagi menjawab dengan telus dan ikhlas (Fauziah et al., 2020). Instrumen soal selidik kajian ini diadaptasi daripada Inventori Persekitaran Fizikal Bilik Darjah (IPFBD) dan Inventori Kesejahteraan dan Keselesaan Pembelajaran (IKKP) oleh kajian Marina, Mohd Ezrizal dan Ramlee (2018). Soal selidik ini terdiri 76 item dengan skala likert 5 poin dan 4 bahagian. Bahagian A: Demografi Responden, Bahagian B: Persekitaran Fizikal Bilik Darjah, Bahagian C: Keselesaan Pengajaran dan Pembelajaran dan Bahagian D: Cadangan Penambahbaikan Persekitaran Fizikal Bilik Darjah PPKI. Berikut merupakan item dalam soal selidik:

Jadual 1: Item soal selidik

\begin{tabular}{clcc}
\hline Bahagian & \multicolumn{1}{c}{ Aspek Kajian } & No. Item & Bilangan Item \\
\hline A & Demografi Responden & $1-6$ & 6 \\
& B & & \\
& Persekitaran Fizikal Bilik Darjah & $1-14$ & 14 \\
& Perabot & $15-28$ & 14 \\
& Ruang & $29-34$ & 6 \\
& Pencahayaan & $35-44$ & 10 \\
& Kualiti Udara & $45-56$ & 12 \\
& Warna & & 8 \\
& Keselesaan Pengajaran dan Pembelajaran & $57-64$ & \\
& Cadangan-cadangan penambahbaikan & & 6 \\
& Dersekitaran fizikal bilik darjah PPKI & $1-6$ & $\mathbf{7 6}$ \\
\hline
\end{tabular}

Pemarkataan skala likert yang digunakan untuk mengkaji indeks keselesaan persekitaran fizikal bilik darjah terdiri daripada: Sangat Setuju (5), Setuju (4), Tidak Pasti (3), Tidak Setuju (2) dan Sangat Tidak Setuju (1). Manakala, pemarkataan skala likert pada indeks keselesaan pengajaran dan pembelajaran adalah Sangat Memuaskan (5), Memuaskan (4), Sederhana (3), Tidak Memuaskan (2) dan Tidak Memuaskan Langsung (1).

Kebolehpercayaan dan kesahan pada instrumen digunakan untuk mengenal pasti ralat pada instrumen. Kesahan adalah ketepatan pada skor skala tinjauan berdasarkan keputusan yang dibuat oleh responden (Johnson \& Morgan, 2016). 2 orang pakar bidang pendidikan khas dan 2 orang pakar bahasa telah membuat semakan dan kesahan instrumen ini. Kajian rintis telah dilaksanakan pada 29 Oktober 2021 sehingga 4 November 2021 dengan melibatkan 2 buah sekolah rendah dan 1 buah sekolah menengah PPKI di daerah Kota Kinabalu. Dapatan menunjukkan soal selidik ini mempunyai tahap kebolehpercayaan yang tinggi dengan $\alpha=.985$. Dapatan kajian rintis adalah seperti dalam Jadual 2 :

Jadual 2: Analisis nilai Alfa Cronbach bagi pemboleh ubah kajian $(\mathrm{n}=30)$

\begin{tabular}{lcc}
\hline Konstruk & Jumlah item & Alpha Cronbach \\
\hline Bahagian B: Persekitaran Fizikal Bilik Darjah & & \\
a) Perabot & 14 & .940 \\
b) Ruang & 14 & .983 \\
\hline
\end{tabular}



DOI: https://doi.org/10.47405/mjssh.v7i1.1236

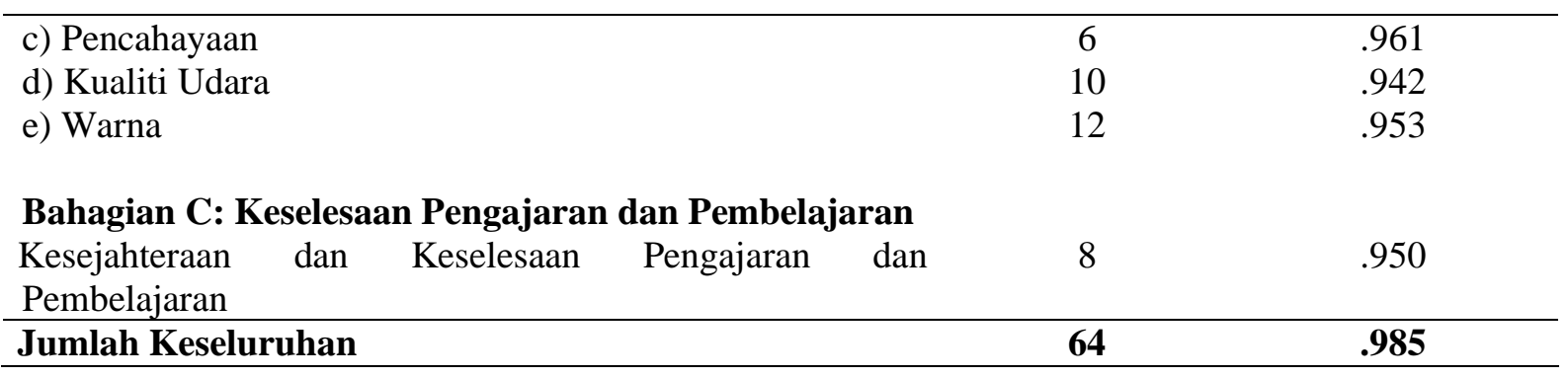

\section{Analisis Data}

Kajian ini menggunakan kaedah analisis deskriptif dan ianya dilakukan pada proses akhir apabila semua dapatan kajian dikumpul (Ang, 2016). Statistical Package of Social Science (SPSS) versi 26 digunakan untuk menganalisis statistik deskriptif yang berbentuk kekerapan, min, sisihan piawai dan peratus. Formula Indeks Keselesaan (IK) dalam kajian ini diadapatsi daripada kajian Siti Nur Aliaa dan Helmi (2018). Berikut merupakan formula yang digunakan:

i. Indeks Keselesaan Persekitaran Fizikal Bilik darjah $($ IKPFBD $)=$

$$
\begin{aligned}
& \mathrm{IKPFBD}=\mathrm{IK}_{\mathrm{p}}+\mathrm{IK}_{\mathrm{r}}+\mathrm{IK}_{\mathrm{w}}+\mathrm{IK}_{\mathrm{ku}}+\mathrm{IK}_{\mathrm{pc}} \\
& \mathrm{IK}_{\mathrm{p}} \quad=\text { Min Indeks Keselesaan Perabot } \\
& \mathrm{IK}_{\mathrm{r}} \quad=\text { Min Indeks Keselesaan Ruang } \\
& \mathrm{IK}_{\mathrm{pc}} \quad=\text { Min Indeks Keselesaan Pencahayaan } \\
& \mathrm{IK}_{\mathrm{ku}}=\text { Min Indeks Keselesaan Kualiti Udara } \\
& \mathrm{IK}_{\mathrm{w}}=\text { Min Indeks Keselesaan Warna }
\end{aligned}
$$

\section{ii. Indeks Keselesaan Pengajaran dan Pembelajaran (IKPP) =}

IKPP = Min Indeks Keselesaan Pengajaran dan Pembelajaran Penskalaan indeks keselesaan dibuat berdasarkan Jadual 3 iaitu Skor Min dan Skala indeks keselesaan pengajaran dan pembelajaran.

Jadual 3: Skor Min dan Skala Indeks bagi keselesaan pengajaran dan pembelajaran

\begin{tabular}{lc}
\hline Nilai Min & Min \\
\hline 1.00 hingga 2.33 & Rendah \\
2.34 hingga 3.67 & Sederhana \\
3.68 hingg 5.00 & Tinggi \\
\hline
\end{tabular}

Sumber : Che Nidzam, Noraini, Mazlini, Marzita \& Mohd Hairy (2013)

\section{Hasil Kajian}

\section{Demografi Responden}

Taburan responden menunjukkan 63 orang (78.8\%) adalah perempuan dan 17 orang lelaki $(21.25 \%)$ terlibat dalam kajian ini. 30 orang (36.25\%) responden berumur antara 31 hingga 40 tahun, 41 hingga 50 tahun adalah 20 orang (25\%), 20 hingga 30 adalah 17 orang $(21.25 \%)$ dan 13 orang (17.5\%) berumur 51 hingga 60 tahun. Guru yang mengajar 11 hingga 20 tahun adalah tertinggi yang bersamaan 30 orang (37.5\%), 10 tahun ke bawah iaitu 29 orang (36.3\%) dan 16 orang mengajar 21 hingga 30 tahun. 90\% responden (72 orang) mempunyai taraf pendidikan ijazah sarjana muda. Berikut merupakan Jadual 4 taburan demografi responden: 
DOI: https://doi.org/10.47405/mjssh.v7i1.1236

Jadual 4: Taburan demografi responden $(n=80)$

\begin{tabular}{llcc}
\hline Kategori & Sub Kategori & Frekuensi & Peratus (\%) \\
\hline Jantina & Lelaki & 17 & 21.25 \\
& Perempuan & 63 & 78.8 \\
Umur & 20 hingga 30 tahun & 17 & 21.25 \\
& 31 hingga 40 tahun & 30 & 36.25 \\
& 41 tahun hingga 50 tahun & 20 & 25 \\
Pengalaman & 51 tahun 60 tahun & 13 & 17.5 \\
mengajar & 10 tahun kebawah & 29 & 36.3 \\
& 11 hingga 20 tahun & 30 & 37.5 \\
Taraf pendidikan & 16 & 20 \\
& 21 hingga 30 tahun & 5 & 6.3 \\
& Lebih daripada 31 tahun & 72 & 90 \\
& Ijazah Sarjana Muda & 7 & 8.8 \\
& Ijazah Sarjana & 1 & 1.25 \\
\hline
\end{tabular}

\section{Indeks keselesaan persekitaran fizikal bilik darjah PPKI MBK Pembelajaran di} daerah Kota Kinabalu

Dapatan pada keseluruhan konstruk menunjukkan indeks keselesaan persekitaran fizikal bilik darjah PPKI MBK Pembelajaran di daerah Kota Kinabalu adalah tinggi $(\mathrm{M}=3.94, \mathrm{SP}=0.627)$. Fizikal bilik darjah PPKI daerah Kota Kinabalu didapati selesa dan memenuhi Universal Design for Learning (UDL).

Berdasarkan Jadual 5, konstruk berikut menunjukkan indeks keselesaan yang tinggi iaitu perabot $(\mathrm{M}=4.00, \mathrm{SP}=0.822)$, pencahayaan $(\mathrm{M}=4.17, \mathrm{SP}=0.527)$ dan kualiti udara $(\mathrm{M}=3.94, \mathrm{SP}=0.689)$. Manakala konstruk ruang $(\mathrm{M}=3.40, \mathrm{SP}=1.114)$ dan warna $(\mathrm{M}=3.50, \mathrm{SP}=0.675)$ adalah pada tahap yang sederhana.

Jadual 5: Indeks keselesaan persekitaran fizikal bilik darjah PPKI $(\mathrm{n}=80)$

\begin{tabular}{lllcc}
\hline No & Konstruk & Min & Sisihan Piawai & Tahap indeks \\
\hline 1. & Perabot & 4.00 & 0.822 & Tinggi \\
2. & Ruang & 3.40 & 1.114 & Sederhana \\
3. & Pencahayaan & 4.17 & 0.527 & Tinggi \\
4. & Kualiti Udara & 3.94 & 0.689 & Tinggi \\
5. & Warna & 3.50 & 0.675 & Sederhana \\
\hline \multicolumn{2}{r}{ Jumlah } & $\mathbf{3 . 9 4}$ & $\mathbf{0 . 6 2 7}$ & Tinggi \\
\hline
\end{tabular}

Indeks keselesaan pengajaran dan pembelajaran guru PPKI MBK Pembelajaran di daerah Kota Kinabalu

Jadual 6 menunjukkan taburan min, sisihan piawai dan indeks keselesaan pengajaran dan pembelajaran guru PPKI daerah Kota Kinabalu. Dapatan menunjukkan indeks keselesaan guru PPKI berada pada tahap tinggi $(\mathrm{M}=3.90, \mathrm{SP}=0.688)$. Merujuk pada indikator Teori Kebajikan Sosiologikal Allardt, keselesaan pengajaran dan pembelajaran dipengaruhi oleh elemen kepunyaan iaitu suasana dan persekitaran. Dapatan kajian ini menunjukkan pengajaran dan pembelajaran dapat dilakukan dengan selesa dalam bilik darjah PPKI. Perabot, warna dan ruang adalah dapat disesuaikan dengan pengajaran dan dapat meningkatkan penglibatan murid. 
Jadual 6: Indeks keselesaan pengajaran dan pembelajaran $(\mathrm{n}=80)$

\begin{tabular}{lccc}
\hline & Min & Sisihan Piawai & Tahap indeks \\
\hline $\begin{array}{l}\text { Keselesaan pengajaran dan } \\
\text { pembelajaran }\end{array}$ & 3.90 & 0.688 & Tinggi \\
\hline
\end{tabular}

\section{Cadangan Penambahbaikan Persekitaran Fizikal Bilik Darjah}

\section{Perabot}

39 orang (48.8\%) mencadangkan penggunaan kerusi jenis berlipat, kaki meja tidak diperbuat daripada besi, warna meja kerusi yang pelbagai, bentuk meja trapezium, diseragamkan, tahan lama dan meja guru dikeluarkan serta penukaran perabot yang baharu. 4 orang (5\%) berpendapat bilangan murid juga harus bersesuaian dengan keluasan dalam bilik darjah dan 5 orang (6.3\%) menyarankan papan tulis yang mempunyai ciri-ciri mudah dibersihkan, interaktif dan besar. 3 orang (3.8\%) berpendapat penggunaan almari perlu dikurangkan, 16 orang $(20 \%)$ menyatakan perabot almari amat diperlukan dalam bilik darjah. 2 orang $(2.5 \%)$ menyatakan penggunaan almari yang siap bina, tempat penyimpanan yang berkunci dan perabot yang kurang kondusif perlu dikeluarkan daripada bilik darjah kerana menyebabkan halangan laluan. 10 orang responden menekankan perabot yang usang perlu ditukar dan susunan perabot juga perlu bersesuaian dengan keluasan kelas.

\section{Ruang pembelajaran}

35 orang (43.8\%) menekankan saiz bilik darjah menentukan keselesaan pembelajaran. 6 orang responden $(7.5 \%)$ menyatakan bilangan murid harus bersesuaian dengan keluasan kelas dan 2 orang (2.5\%) menyarankan pengurangan bilangan murid. Antara cadangan bilangan murid adalah 5 orang dalam sesebuah kelas. Turut ditekankan adalah pembinaan pembahagi kelas bagi kelas yang bergabung. 6 orang (20\%) menyarankan meja kerusi yang rosak perlu dikeluarkan dalam bilik darjah, meja perlu bersaiz besar dan susunan meja yang berkonsepkan PAK 21 serta pengurangan perabot dalam ruang pembelajaran akan melancarkan pembelajaran. 2 orang $(2.5 \%)$ mencadangkan pembinaan sudut-sudut tambahan seperti sudut bacaan. Turut dicadangkan adalah pembinaan bilik guru, dinding kelas yang berupaya menyokong akustik atau kalis bunyi, pemasangan almari secara siap bina, rak penyimpanan buku dan penggunaan kipas serta penghawa dingin.

\section{Bilangan murid}

Seramai 31 orang responden (38.8\%) berpendapat bilangan murid yang ideal dalam sesebuah kelas adalah 7 hingga 10 orang. Bagi 21 responden (26.3\%), 4 sehingga 6 orang adalah jumlah yang ideal dalam bilik darjah PPKI. Manakala 2 orang (2.5\%) menekankan bilangan murid seharusnya mengikut kesesuaian saiz bilik darjah iaitu bilik darjah sedia ada sepatutnya hanya dapat menampung bilangan murid seramai 6 hingga 7 orang sahaja.

\section{Pencahayaan}

Daripada cadangan 27 responden (33.8\%), jenis lampu yang dicadangkan iaitu Led (6.3\%), kalimantang (7.5\%) dan lampu mentol atau tungsten (2.5\%). 14 cadangan (17.5\%) menyatakan bilangan unit lampu perlu ditambah dalam bilik darjah PPKI agar pencahayaan dapat diseragamkan dan dioptimumkan. Bagi 21 orang responden (26.3\%), jenis dan reka bentuk tingkap berupaya meningkatkan tahap pencahayaan. Manakala 9 orang responden (11.3\%) mencadangkan tingkap perlu diperluaskan, $8.8 \%$ (7 orang) menyarankan penggunaan jenis tingkap gelangsar kerana lebih selamat dan berupaya mengurangkan ketidakselesaan pada penglihatan akibat pantulan cahaya. 1 daripada responden $(1.3 \%)$ menyatakan kedudukan tingkap perlulah strategik dan 2 orang $(2.5 \%)$ menekankan 
jenis tingkap yang terdapat dalam bilik darjah perlu menepati ciri-ciri keselamatan dan ditambah mengikut keperluan pencahayaan.

\section{Kualiti pengudaraan}

18 orang $(22.5 \%)$ mencadangkan penggunaan tingkap bagi meningkatkan pengudaraan secara semula jadi dalam bilik darjah. Berikut merupakan cadangan yang disarankan iaitu 3 orang (3.8\%) tingkap jenis terbuka, $5 \%$ (4 orang) tingkap gelangsar dan 1 orang (1.3\%) berpendapat tingkap PPKI tidak perlu dipasang jaring. 3 orang (3.8\%) menekankan keperluan memastikan tingkap kelas sentiasa dibuka dan 1 orang $(1.3 \%)$ mencadangkan jenis tingkap perlu ditukar kepada yang lebih bersesuaian dan selamat untuk semua MBK.

\section{Warna}

18 orang responden mencadangkan warna kuning misalnya kuning muda, putih (16 cadangan) dan hijau (10 cadangan), biru (29 cadangan), merah muda ( 2 cadangan) dan biru (2 cadangan). Lain-lain warna ialah ungu dan merah. 12 responden menyarankan bilik darjah PPKI perlu menggunakan warna yang terang. Lain-lain cadangan adalah PPD perlu menyediakan peruntukan peralatan cat, penggunaan warna yang cat yang dapat memberi kesan luas dan pemilihan warna yang kurang gelap. Penggunaan warna cat yang tidak melebihi daripada 2 jenis warna, menampakkan ruang kelihatan lebih bersih, tahan lama, tidak berbau dan warna yang mudah dibersihkan.

\section{Perbincangan Kajian}

Dapatan kajian menunjukkan fizikal bilik darjah PPKI mempunyai tahap keselesaan yang tinggi. Walaupun analisis indeks keselesaan keseluruhan adalah tinggi, 43.8\% guru-guru PPKI mencadangkan saiz bilik darjah perlu diperluaskan. Ini dapat dirujuk pada keperluan beberapa fizikal PPKI yang menumpang bangunan kelas perdana dan fizikal sedia ada yang terhad. Dapatan ini menyokong kajian Norsafiah et al. (2021) dan Anselm et al. (2018) iaitu bangunan sekolah di Malaysia khususnya kelas PPKI tidak memenuhi standard reka bentuk bilik darjah. Berikut merupakan bentuk-bentuk fizikal bilik darjah PPKI yang terlibat dalam kajian ini:

Gambar 1: Bilik darjah PPKI tanpa dinding pemisah (A), ukuran ruang yang dikongsikan dengan 3 Kelas (20 kaki x 30 kaki) (B) dan Kelas berukuran 10 kaki x 10 kaki (C)
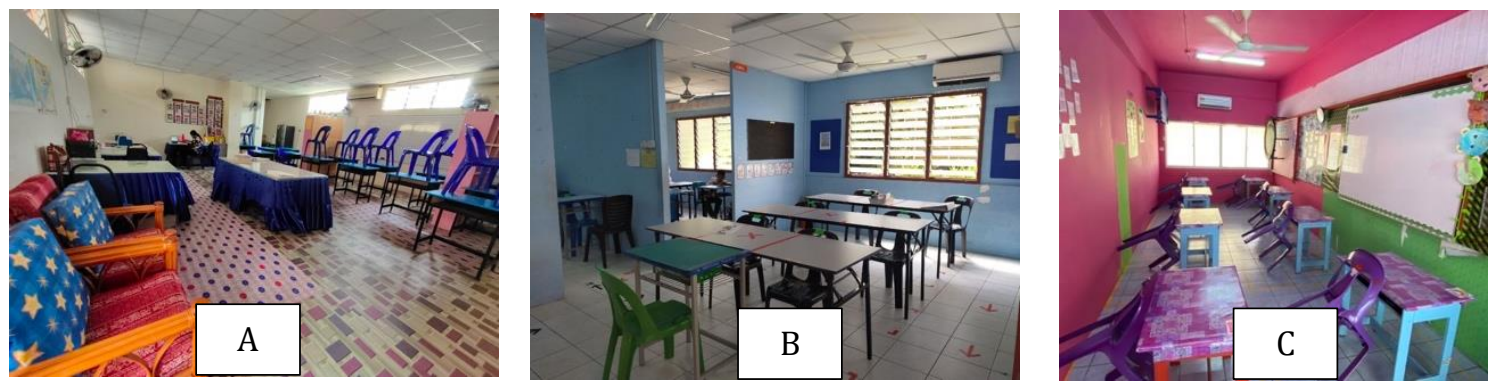

Impak daripada fizikal yang terhad akan menyumbang pada isu bilik darjah yang kurang kondusif seperti dalam kajian Norwahidah et al. (2019) dan Mohd Hanafi et al. (2013). Pengurusan pendidikan perlu memastikan bilik darjah adalah bersesuaian dengan keperluan pendidikan dan kepelbagaian MBK. Kajian ini mendapati prestasi kehadiran tidak dipengaruhi oleh fizikal pembelajaran seperti yang dinyatakan dalam kajian oleh Norsafiah et al. (2021) dan Mohd Zuri (2020). Keadaan semasa Covid-19 mempengaruhi keputusan ibu bapa dalam membenarkan MBK datang ke sekolah.

Indeks keselesaan guru mendapati guru PPKI tidak mengalami masalah sokongan dana dalam penyediaan bahan pengajaran seperti yang dinyatakan dalam kajian Farah et al. (2021) atau kelelahan mengurus tingkah laku (Mohd Arafat et al., 2021). Keadaan fizikal yang terhad berupaya menjadi 
halangan bagi guru dalam melaksanakan aktiviti pembelajaran dan ini disokong oleh kajian Amalina dan Azita (2016). Faktor penyusunan semula bilik darjah berdasarkan garis panduan pembukaan sekolah telah mewujudkan norma baharu dalam pengajaran. Guru perlu mengurus bilik darjah dengan sistematik kerana persekitaran pekerjaan yang kondusif berupaya meningkatkan motivasi guru (Ahmad Syarifuddin et al., 2021; Junaidah et al., 2021; Mohd Arafat et al., 2021). Dapatan kajian ini menunjukkan keadaan fizikal sekolah khususnya bilik darjah berdasarkan Teori Kebajikan Sosiologikal Allardt mempengaruhi perkembangan komunikasi dan kawalan disiplin antara murid dan guru.

Cadangan mengurangkan penempatan murid dalam sesebuah kelas adalah relevan dengan situasi semasa PPKI. 31 responden (38.8\%) dengan cadangan bilangan murid yang ideal ialah 7 hingga 10 orang adalah tidak berpadanan dengan saranan KPM iaitu hanya 50\% murid berada dalam sesebuah kelas. Dapatan ini menyokong kajian Norsafiah et al. (2021) iaitu bilangan murid yang ideal harus berdasarkan kapisiti bilik darjah. Selain daripada itu, pengurusan pendidikan juga perlu menilai kesesuaian bilik darjah berdasarkan perkembangan emosi dan tingkah laku MBK. Saranan penggunaan tingkap, kipas dan membuka pintu bagi bilik darjah adalah berpadanan dengan dapatan kajian Chillon et al. (2021). Cadangan ini bukan sahaja membantu pengaliran udara yang baik tetapi juga menyingkirkan halangan pada tahap pencahayaan.

Penggunaan warna dinding yang ceria dan sejuk berupaya merangsang perkembangan kognitif, visual (Nyoman et al., 2021) dan psikologi murid (Qonita \& Yoyon, 2018). Saranan penggunaan warna yang cerah, ceria dan gabungan warna adalah berpadanan dengan kajian Martin dan Wilkins (2021) yang mencadangkan warna kuning. Namun demikian, dapatan kajian Muezzinoglu et al. (2020) dan Roslinda et al. (2019) mendapati warna sejuk (biru) adalah lebih efektif berbanding warna cerah dalam merangsang perkembangan sosial dan tingkah laku murid. Rumusannya, pemilihan warna dinding darjah perlu disesuaikan mengikut keadaan fizikal bilik darjah.

\section{Kesimpulan}

Indeks keselesaan persekitaran fizikal bilik darjah menunjukkan bilik darjah PPKI adalah memenuhi konsep Universal Design for Learning (UDL). Guru dan murid berupaya mengakses persekitaran pembelajaran tanpa halangan. Malah, suasana pembelajaran khususnya tahap pencahayaan, pengudaraan dan warna membolehkan murid mengalami pembelajaran dengan kondusif. Pengurusan dan penyusunan semula bilik darjah berdasarkan garis panduan KPM meningkatkan akses dan mengurangkan halangan MBK terhadap bilik darjah. Ruang pembelajaran yang kondusif berupaya membentuk disiplin bilik darjah berkesan. Oleh itu, guru perlu memastikan ruang pembelajaran berada dalam keadaan yang selesa sebelum proses pendidikan dilaksanakan.

Implikasi daripada kajian ini menunjukkan faktor fizikal pembelajaran adalah penting dalam mewujudkan bilik darjah yang selesa. Sehubungan itu, Kementerian Pendidikan Malaysia perlu sentiasa membuat pantauan pada fizikal sekolah. Persekitaran bilik darjah bukan sahaja berupaya mempengaruhi perkembangan pendidikan tetapi juga memberi kesan kepada pembentukan disiplin murid. Dapatan ini diharapkan dapat membantu pengurusan pendidikan seperti KPM, JPN dan PPD dalam membuat perancangan pendidikan. Hal ini bukan sahaja dapat meningkatkan kualiti pendidikan bagi MBK tetapi juga dapat memastikan kebajikan guru terjaga.

Limitasi pada kajian ini hanya melibatkan 80 guru PPKI daerah Kota Kinabalu, diharapkan kajian akan datang dapat melibatkan semua sekolah yang mempunyai PPKI. Kajian ini akan berupaya menyumbang kepada perkembangan pengurusan bilik darjah yang efektif. Populasi kajian juga perlu diperluaskan dengan melibatkan pengurusan sekolah iaitu pengetua, penolong kanan dan guru-guru inklusif. Pandangan dan maklum balas daripada mereka dapat membantu penilaian kajian dengan lebih berkesan. Pengkaji akan datang juga diharapkan dapat mengkaji hubungan kesesuaian bilik darjah PPKI dengan masalah MBK. 


\section{Rujukan}

Ahmad Syarifuddin Che Abd Aziz, Tumisah binti Akim, Abdul Halim Bin Ruseh, Sarina Binti Mail, Mohd Norazmi bin Nordin. (2021). Elements of facility in job satisfaction of special education teachers in Malaysia. Turkish Journal of Computer and Mathematics Education, 12(11), 52395243.

Ajilin Tawan, Mohamad Nizam Nazarudin, Zakiah Noordin, Mohd Malik Tu \& Norlijah Watinin. (2020). Hubungan motivasi, kecerdasan emosi dan efikasi dengan kepuasan kerja guru di sekolah rendah. International Research Journal of Education and Sciences (IRJES), 4(1), 1-12.

Akhiar Bin Pardi \& Shamsina Shamsuddin. (2015). Pengurusan bilik darjah dan tingkah laku. Pelangi Professional Publishing Sdn. Bhd.

Amalina Binti Razali \& Azita binti Ali. (2016). Faktor-faktor yang mempengaruhi tahap stres guru pendidikan khas. Online Journal for Tvet Practitioners, 1(1), 1-7.

Aney Marinda Muhammad Amin \& Norasmah Othman. (2019). Pengurusan bilik darjah guru baharu yang mengikuti program pembangunan guru baharu (PPGB). Jurnal Pendidikan Malaysia, 44(1), 21-27.

Ang Kean Hua. (2016). Pengenalan rangka kerja metodologi dalam kajian penyelidikan: Satu kajian literatur. Malaysian Journal of Social Sciences and Humanities (MJSSH), 1(2), 17-24. https://doi.org/10.47405/mjssh.v1i2.8

Anselm Dass Mathalamuthu, Nik Lukman Nik Ibrahim, Vignes Ponniah, Mohd Wira Mohd Shafiei \& Radzi Ismail. (2018). Illuminance uniformity using public works department (PWD) standard design for public schools classroom design in Malaysia. Journal of Advanced Research in Fluid Mechanics and Thermal Sciences, 52(2), 205-214.

Che Nidzam Che Ahmad, Noraini Mohamed Noh, Mazlini Adnan, Marzita Putih \& Mohd Hairy Ibrahim. 2013. Pengaruh persekitaran fizikal bilik darjah terhadap tahap keselesaan pengajaran dan pembelajaran. Jurnal Pendidikan Bitara UPSI, 6:1-7.

Chillon, S, A., Millan, M., Aramendia, I., Fernandez-Gamiz, U., Zulueta, E. \& Mendaza-Sagastizabal, $X$. (2021). Natural ventilation characterization in a classroom under different scenarios. International Journal of Environmental Research and Public Health, 18(10), 1-13. http://dx.doi.org/10.3390/ijerph18105425

Cohen, L., Manion, L. \& Morrison, K. (2018). Research methods in education. Routledge.

Doulos, L.T., Kontadakis, A., Madias, E.N., Sinou, M. \& Tsangrassoulis, A. (2019). Minimizing energy consumption for artificial lighting in a typical classroom of a Hellenic public school aiming for near Zero Energy Building using LED DC luminaires and daylight harvesting systems. Energy \& Buildings, 194, 201-217. https://doi.org/10.1016/j.enbuild.2019.04.033

Doyle, W. (1980). Classroom management. Kappa Delta Pi Publication.

Ernisuhani Mohamad Zamri, Asmat Ismail \& Azizah Md Ajis. (2019). Thermal comfort in naturally ventilated classroom: A literature review. International Journal of Property Sciences, 9(1), 27-37. https://doi.org/10.22452/ijps.vol9no1.3

Farah Adibah Binti Ibrahim, Biamin Ahmad, Rehah Binti Ismail, Harlina Binti Ismail, Mohd Norazmi Bin Nordin. (2021). Resource elements in the construct of special education teacher workload in Malaysia. Turkish Journal of Computer and Mathematics Education, 12(11), 5289-5293.

Farjana Rahman \& Muhammad Mozammel Hossain Tuhin. (2019). Daylight impact on learning environment in classrooms of secondary high school at Ishwardi, Pabna, Bangladesh. International Research Journal of Engineering and Technology (IRJET), 6(10), $1148-1153$.

Fauziah Ibrahim, Khadijah Alavi \& Nazirah Hassan. (2020). Penulisan tesis kajian kualitatif dan kuantitatif. Universiti Kebangsaan Malaysia.

Hamdi Bin Ishak, Ab Halim Bin Tamuri, Rosadah Binti Abdul Majid \& Safani Bin Bari. (2012). Amalan pengajaran guru dalam pengajaran dan pembelajaran pendidikan islam di Sekolah Kebangsaan Pendidikan Khas (masalah pendengaran). Journal of Islamic and Arabic Education, $4(2), 11-24$.

Gislason, N. (2011). Building Innovation. History, cases and perspectives on school design. Backalong Books. 
Ibhadode, O., Okougha, F. A., Nwafor, C. O. \& Essang, N. (2017). An experimental-study on ventilation of public schools in Akure, Oshogbo and Ado-ekiti cities in South-western Nigeria. IOSR Journal of Mechanical and Civil Engineering, 14(5), 34-43.

Izzati Zarin, Kuldip Kaur, Shafinar Ismail, Yap Voon Choong \& Chew Sze Chiong. (2021). Constructing a new stress index for teachers in Malaysia. International Journal of Academic Research in Business and Social Sciences, 11(7), 859-863. http://dx.doi.org/10.6007/IJARBSS/v11-i7/10541

Johnson, R.L \& Morgan, G.B. (2016). Survey scales: A guide to development, analysis and reporting. The Guilford Press.

Juairiah Marjonet, Siti Hajar Abu Bakar Ah \& Noralina Omar. (2020). Pementoran dalam program pembangunan guru baharu Kementerian Pendidikan Malaysia (Mentoring in the new teacher development program by the Ministry of Education Malaysia). The Malaysian Journal of Social Administration, 14(2), 79-95.

Junaidah Yusof, Farah Adibah Binti Ibrahim, Senin M.S, Hilmiah Binti Haji Hassan \& Mohd Norazmi Bin Nordin. (2021). Elements of work environment in the construct of special education teacher workload in Malaysia. Turkish Journal of Computer and Mathematics Education, 12(11), 52845288.

Kanakri, S.M., Shepley, M., Tassinary, L.G., Varni, J.W. \& Fawaz, H.M. (2016). An observational study of classroom acoustical design and repetitive behaviours in children with autism. Environment and Behavior, 49(8), 847-873. https://doi.org/10.1177\%2F0013916516669389

Konu, A., Alanen, E., Lintonen, T. \& Rimpela, M. (2002). Factor structure of the school well-being model. Health Education Research, 17(6), 732-742. https://doi.org/10.1093/her/17.6.732

Korpershoek, H., Harms, T., De Boer, H., Van Kuijk, M. \& Doolaard. S. (2016). A meta-analysis of the effects of classroom management strategies and classroom management programs on students' academic, behavioral, emotional and motivational outcomes. Review of Educational Research, 86(3), 643-680. https://doi.org/10.3102\%2F0034654315626799

Marina Awang, Mohd Ezrizal Zakaria \& Ramlee Ismail. (2018). Hubungan persekitaran fizikal bilik darjah dan kesejahteraan dan keselesaan pembelajaran dan pengajaran. Management Research Journal, 8(1), 86-99.

Martin, R \& Wilkins, J. (2021). Creating visually appropriate classroom environments for students with Autism Spectrum disorder. Intervention in School and Clinic, 1-6. https://doi.org/10.1177\%2F10534512211014882

Mohd Arafat Bin Jaafar, Muhammad Talhah Ajmain@Jima'ain, Mazita Binti Ahmad Subaker, Kavita Doraisamy, Mohd Norazmi Bin Nordin. (2021). Special education teachers task load in Malaysia: A review. Turkish Journal of Computer and Mathematics Education, 12(11), 5333-5337.

Mohd Hanafi Mohd Yasin, Hasnah Toran, Mohd Mokhtar Tahar, Safani Bari, Siti Nur Nadirah Ibrahim \& Rozniza Zaharudin. (2013). Bilik darjah pendidikan khas pada masa kini dan kekangannya terhadap proses pengajaran. Asia Pacific Journal of Educators and Education, 28, $1-9$.

Mohd Razimi Bin Husin, Muhammad Farhan Bin Suhaimi, Suhailah Binti Md Hamil, Nurul Natasha Binti Azmi, Nurul Umaira Juliana Binti Roslid, Nur Nabilah Binti Zainal, Nor Balqis Binti Kamaruddin, Nur Izzsufi Binti Hamizi \& Nurul Zulaikha Binti Ismawi. (2020). Masalah Pembelajaran untuk Pelajar Pendidikan Khas: Dana dan Prasarana. International Journal of Humanities, Management and Social Sciences, 3(1), 1-10. https://doi.org/10.36079/lamintang.ijhumass-0301.106

Mohd Zuri Ghani. (2020). Dimensions of learning styles among students with Attention DeficitHyperactivity Disorder (ADHD) in Malaysia. ASEAN Journal of Open Distance Learning, 12(1): 91-99.

Muezzinoglu, M.k., Hidayetoglu, M.L. \& Yildirim, K. (2020). The effects on the perceptual evaluations of students for the wall colors used in educational spaces. MEGARON / Ylldiz Technical University, Faculty of Architecture E-Journal, 15(1), 1-12. http://dx.doi.org/10.14744/megaron.2020.87369

Ng Yi Ming, Peter Voo Su Kiong \& Ismail Maakip. (2019). The relationships between risk factors and musculoskeletal disorders among teachers: an exploratory investigation in Malaysia. ProceedingKuala Lumpur International Communication, Education, Language and Social Sciences 13 (KLiCELS 13). ResearchGate. $\quad$ https://www.researchgate.net/profile/Ismail- 
Maakip/publication/336796564 The Relationships Between Risk Factors And Musculoskelet al Disorders Among Teachers An Exploratory Investigation In Malaysia/links/5db264d0299 bf111d4c7255c/The-Relationships-Between-Risk-Factors-And-Musculoskeletal-DisordersAmong-Teachers-An-Exploratory-Investigation-In-Malaysia.pdf

Norfisah Mat Rabi. (2016). Transformasi pendidikan murid kurang upaya. Penerbit Universiti Pendidikan Sultan Idris.

Norhaslin Nordin, Muhammad Azzam Ismail \& Ati Rosemary Mohd Ariffin. (2019). Ventilation blocks: Design feature in Malaysia public schools. Journal of Design and Built Environment, 19(1), 1-12. https://doi.org/10.22452/jdbe.vol19no1.1

Norsafiah Norazman, Adi Irfan Che Ani, Wan Norisma Wan Ismail, Afifuddin Husairi Hussain \& Khairul Nizam Abdul Maulud. (2021). Indoor environmental quality towards classrooms' comforts level: ase study at Malaysian secondary school building. Applied Sciences, 11(3), 2-16. https://doi.org/10.3390/app11135866

Norwahidah Mihat, Mohd Hanafi Mohd Yassin \& Mohd Mokhtar Tahar. (2019). Teachers' views on classroom infrastructure facilities in special education integration program in primary school. Journal of ICSAR 3(1), 54-57. http://dx.doi.org/10.17977/um005v3i12019p054

Nyoman Larry Julianto, Cokorda Alit Artawan \& Wayan Agus Eka Cahyadi. (2021). Keterlibatan ilustrasi dan warna sebagai stimulus visual dalam konsep 'Interaksi ruang belajar' pada sekolah dasar kelas 1-3 di Bali. ANDHARUPA: Jurnal Desain Komunikasi Visual \& Multimedia, 7(2), 389-400.

Qonita Fardlillah \& Yoyon Suryono. (2019). Physical environment classroom: Principles and design elements of classroom in early childhood education. International Conference on Special and Inclusive Education (ICSIE 2018). Atlantis Press. https://www.atlantispress.com/proceedings/icsie-18/55917541

Rands, M.L. \& Gansemer-Topf, A.M. (2017). The room itself is active: How classroom design impacts student engagement. Education Publications, 6(1), 26-33.

Roslinda Ghazali, Siti Rasidah Md. Sakip \& Ismail Samsuddin. (2019). Creating positive environment for autism using sensory design, Design \& Creative Environment, 4(10), 19-26. https://doi.org/10.21834/e-bpj.v4i10.1618

Scrivener, J. (2012). Classroom management techniques. Cambridge University Press.

Sieberer-Nagler, K. (2016). Effective classroom-management \& positive teaching. English Language Teaching, Canadian Center of Science and Education, 9(1), 163-172.

Siti Nur Aliaa Roslan \& Helmi Zulhaidi Mohd Shafri. (2018). Developing building comfort index from building climate factors in a tropical urban environment. IOP Conference Series: Earth and Environmental Science $169 . \quad$ Research Gate. https://www.researchgate.net/publication/326727819_Developing_building_comfort_index_from _building_climate_factors_in_a_tropical_urban_environment

Suhaimi Bin Kamarudin \& Muhamad Suhaimi Taat. (2020). Faktor tingkah laku pelajar, kekangan masa, beban tugas dan tekanan kerja dalam kalangan guru. Malaysian Journal of Social Sciences and Humanities (MJSSH), 5(9), 114 - 124. https://doi.org/10.47405/mjssh.v5i9.481

Taylor, S.J., Bogdan, R. \& DeVault, M.L. (2016). Introduction to qualitative research methods a guidebook and resource. John Wiley \& Sons, Inc.

Tegtmejer, T. (2019). ADHD as a classroom diagnosis. An exploratory study of teachers' strategies for addressing "ADHD classroom behavior". Emotional and Behavioral Difficulties, 24(3), 239253. https://doi.org/10.1080/13632752.2019.1609271

Wahyuni Masyidah Md. Isa, Noor Azlina Mohamed Khalid \& Muhammad Fauzi Zainuddin. (2014). Peranan ergonomik dalam reka bentuk kerusi sekolah: Kajian kes di sekitar Perlis, Kedah dan Pulau Pinang. Conference Proceeding: 1st International Conference On Creative Media, Design \& Technology (Reka2014), hlm 1-7. Research Gate. https://www.researchgate.net/publication/338914536_Peranan_Ergonomik_Dalam_Rekabentuk_ Kerusi_Sekolah_Kajian_Kes_Di_Sekitar_Perlis_Kedah_Dan_Pulau_Pinang

Wan Nur Amirah Ibrahim, Zainora Mohammed, Norliza Mohamad Fadzil, Sumithira Narayanasamy \& Mohd Izzuddin Hairol. (2018). Perubahan tahap pencahayaan dalam bilik darjah di sebuah sekolah pendidikan khas cacat penglihatan dan perbandingan tahap pencahayaan di bawah keadaan pencahayaan yang berbeza. Sains Malaysian ,47(8), 1835-1842. http://dx.doi.org/10.17576/jsm-2018-4708-23 
Malaysian Journal of Social Sciences and Humanities (MJSSH), Volume 7, Issue 1, (page 59 - 72), 2022

DOI: https://doi.org/10.47405/mjssh.v7i1.1236

Zarina Abd Aziz. (2019). Cabaran yang dihadapi oleh guru dalam pendidikan inklusif di kalangan murid implan koklea. International Conference on Special Education in Southeast Asia Region 9th Series 2019. Academia Edu. 